\section{1/13 and J/8 Sweetpotato Mass Selection Populations}

\author{
Alfred Jones ${ }^{1}$, Philip D. Dukes ${ }^{2}$, and James M. Schalk ${ }^{3}$ \\ U.S. Vegetable Laboratory, Agricultural Research Service, U.S. \\ Department of Agriculture, Charleston, SC 29414
}

\section{Max G. Hamilton ${ }^{4}$}

Clemson University Edisto Research and Education Center, Blackville, SC 29817

\begin{abstract}
Additional index words. Ipomoea batatas, disease resistance, insect resistance, vegetable breeding
\end{abstract}

Two sweetpotato (Ipomoea batatas (L.) Lam] germplasm populations were developed through mass selection of open-pollinated clones from widely diverse origins to provide a means of using plant introductions and other exotic materials to develop enhanced germplasm with a wide genetic base. Selection was for multiple insect, nematode, and disease resistances in combination with other desirable production and market qualities. The general procedures and techniques followed have previously been presented by Jones et al. (1986). In both populations, selected plants served as seed parents for the next generation and were not reentered in subsequent generations. Pollination was accomplished by feral insects. These two germplasm releases are designated $1 / 13$ and $\mathrm{J} / 8$ in accordance with a system of labeling various genetically isolated mass selection populations with capital letters and indicat-

Received for publication 2 Oct. 1990. The cost of publishing this paper was defrayed in part by the payment of page charges. Under postal regulations, this paper therefore must be hereby marked advertisement solely to indicate this fact.

${ }^{1}$ Research Geneticist.

${ }^{2}$ Research Plant Pathologist.

${ }^{3}$ Research Entomologist.

${ }^{4}$ Associate Professor (retired) ing generations fractionally. Thus, $1 / 13$ and $\mathrm{J} / 8$ refer to generations 13 and 8 of populations I and $\mathrm{J}$, respectively.

\section{Origin}

Mass selection population 1/13 was initiated in 1969 by open pollination of 163 plants (Cuthbert and Jones, 1972; Jones and Cuthbert, 1973) and 64 plants resistant to fusarium wilt in other studies. The gene base was further widened by introgression from other sources in generations 3 to 8 . Details of the first six generations were presented by Jones et al. (1976). By generation 7, some $25 \%$ of the population was traced to plant introductions (PI) and other foreign sources. PI 318846 and 'Jasper' were introgressed in $1 / 8$ to assure some soil rot [Streptomyces ipomoea (Person \& W.J. Martin) Wakman \& Henerici] resistance. Selection was shifted from 1year cycles to 2 -year cycles in $1 / 7$ to allow more precise evaluation of progenies. Considering the original selections used and those introgressed, the following 18 PIs contributed as seed parents: 153906, 153907, 208029, 208805, 208806, 259164, 277636, 286621, 286622, 286630, 308196, 308203, and 324885 . selected from insect-resistance studies 308208 , 318846, 318848, 318856, 318858,
Mass selection population $\mathrm{J}$ was initiated in 1976 by open pollination of 409 clones representing collections from Taiwan (158), Japan (24), New Guinea (38), Hawaii (14), Nigeria (18), Timor (15), Thailand (4), Peru (7), Cuba (8), Phillipines (2), Puerto Rico (3), New Zealand (1), Guatemala (4), Uruquay (1), Cook Islands (1), Marquesa Island (1), Spain (1), Canada (1), other U.S. breeding programs (22), and our previous wide gene base populations (85). Twenty-two PI sources were used in the first generation: 208805, 208806, 280036, 277636, 286619, 286621, 286622, 286630, 296116, 308196, $318846,318851,318855,318856,320453$, 324885, 344124, 344140, 399161, 399162, 399163, and 399164. The remaining initiating plants were made up of other clonal and seed accessions. Selection in the first three generations was based on keeping the most acceptable plants from each of the original sources. Seed were harvested from 100 clones of $\mathrm{J} / \mathrm{l}$, representing 20 geographical sources. However, selected plants from some sources of $\mathrm{J} / 1$ and $\mathrm{J} / 2$ failed to flower. Therefore, 12 clones from $\mathrm{J} / 1$ and 22 clones from $\mathrm{J} / 2$ were grafted to I. carnea Jacq. ssp. fistulosa (Mart. ex. Choisy) D. Austin (Dukes et al., 1990) to promote flowering and then were reentered in following polycross generations $J / 2$ and $J / 3$. Seed from $J / 3$ were bulked to start $\mathrm{J} / 4$; thereafter, source identities were discontinued. Originating sources were estimated to be $\approx 15 \%$ from U.S. programs, with the rest divided about equally between PI and other exotic sources.

Seedlings in $J / 2$ and $J / 3$ were started in the greenhouse. Those with purple discoloration of root flesh or very fine twining vines were discarded, and $\approx 650$ were moved to the polycross nurseries. Vine cuttings were used for five-plant plots to obtain yield, flesh color, shape, general appearance, and insect damage ratings. Seed were harvested from the best 225 plants in $J / 2$ and the best 198 in $\mathrm{J} / 3$ to start subsequent generations. In $\mathrm{J} / 4$ and following generations, 2-year selection cycles were used to allow for more precise 
evaluations of yield and disease and insect resistance, as well as storage quality and sprouting behavior. With the increased precision of selection, the numbers of plants polycrossed during each cycle were reduced to $64,60,44,30$, and 42 in $\mathrm{J} / 4$ to $\mathrm{J} / 8$. Bulked seed from the highest rated $\mathrm{J} / 8$ plants were used for this release.

\section{Description}

In general, the frequencies and levels of resistances to a broad spectrum of pests are quite high. Selection for resistances to the following diseases were made each generation beginning in $1 / 4$ and $\mathrm{J} / 4$ : stem rot (fusarium wilt) [Fusarium oxysporum f. sp. batatas (Wr.) Synd. \& Hans.]; southern root knot [Meloidogyne incognita (Kofoid \& White) Chitwood] (races 1 and 3 and local populations); sclerotial blight in the plant bed and circular spot of storage roots in the field, both incited by Sclerotium rolfsii Sacc. Annually, some clones were tested for internal cork [a strain of feathery mottle virus (FMV)], and low frequencies of susceptibility were noted in both populations. Other diseases considered during selection included russet crack (a strain of FMV), leaf blight [Phyl- losticta batatas (Theum.) Cke.], and field and storage rots. Selections were made each generation for resistance to the following soil insects: the WDS complex (wireworm- Diabrotica-Systena), which includes the southern potato wireworm (Conoderus falli Lane), the tobacco wireworm $(C$. vespertinus Fabricius), the banded cucumber beetle (Diabrotica balteata Le Conte), the spotted cucumber beetle (D. undecimpunctata howardi Barber), the elongate flea beetle (Systena elongata Fabricius), the pale-striped flea beetle ( $S$. blanda Melsheimer), and $S$. frontalis Fabricius (a flea beetle), and to the sweetpotato flea beetle (Chaetocnema confinis Crotch.) and the white grub (Plectris aliena Chapin).

Selection was also made for various production and marketing needs, such as yield, storability, sprouting, orange flesh, fusiform shape, low fiber, low flesh oxidation, appearance, texture, and flavor of baked roots. Plants of these populations generally flower profusely without special treatment, making them especially useful in breeding.

\section{Availability}

Limited numbers of true seed of $1 / 13$ and
$\mathrm{J} / 8$ will be made available to bona fide sweetpotato breeders upon written request. Requests should be addressed to A.J., U.S. Vegetable Laboratory, 2875 Savannah Highway, Charleston, SC 29414.

\section{Literature Cited}

Cuthbert, F.P., Jr., and A. Jones. 1972. Resistance in sweetpotatoes to Coleoptera increased by recurrent selection. J. Econ. Entomol. 65:1655-1658.

Dukes, P.D., A. Jones, and J.M. Schalk. 1990. 'Inducer', a tree morning glory rootstock cultivar for use in breeding sweetpotatoes. HortScience 25(2):238-239.

Jones, A. and F.P. Cuthbert, Jr. 1973. Associated effects of mass selection for soil-insect resistances in sweetpotato. J. Amer. Soc. Hort. Sci. 98:480-482.

Jones, A., P.D. Dukes, and F.P. Cuthbert, Jr. 1976. Mass selection in sweet potato: Breeding for resistance to insects and diseases and for horticultural characteristics. J. Amer. Soc. Hort. Sci. 101(6):701-704

Jones, A., P.D. Dukes, and J.M. Schalk. 1986. Sweet potato breeding, p. 1-35. In: M.J. Bassett (ed.). Breeding vegetable crops. AVI, Westport, Conn. 